\title{
Effectiveness of Counter-Trafficking Response in Albania
}

\author{
Merita H. Meçe ${ }^{1 *}$ \\ ${ }^{1}$ Clemson University, Institute of the Family and Neighborhood Life, Clemson, South Carolina 29634, USA.
}

KEYWORDS

Human trafficking

Counter-trafficking

response

Rights-based approach

Effectiveness

Gender violation of

human rights

\section{A BSTRACT}

Human trafficking is a new phenomenon of Albanian post-socialist society which significantly increased during the difficult years of its transformation from centralized state-led economy to market economy. Both economic and political instability contributed to its size, nature and multiple dynamics. Drawing on a rights-based approach to human trafficking, this paper examines the effectiveness of the counter-trafficking response of the Albanian government with a special emphasis on prevention, protection and prosecution. Using secondary data and reviewing various country strategic documents, it highlights a range of weaknesses and challenges which have hindered its effectiveness over years. It concludes that successful and effective counter-trafficking response requires well rounded and coordinated gender sensitive, victim-centred, holistic and human rights-based efforts. Combined with adequate law enforcement, they will sustainably tackle the full spectrum of this problem.

\section{Introduction}

Human trafficking is a form of modern day slavery which has been fastly moving from the margins to the mainstream concern (UN 2010). Taking place in a broader context of the complex process of globalization (Friman and Reich 2007) combined with illegal migration and human smuggling (Sun-Suon 2015), it has reached epidemic proportions (Smith 2014)

\footnotetext{
* Contact address: mmece@g.clemson.edu or mmec001@yahoo.co.uk (M. H. Meçe)
} 
victimizing many persons and continuously violating their human rights (Shelley 2010). This multi-dimensional phenomenon is affecting almost every country in the world (UNODC 2014). Even though there are no exact data about trafficked persons globally (Roth 2012; Sun-Suon 2015), estimates indicate that at least 700,000 people are trafficked each year worldwide (UNFPA 2007), while during the period 2007-2010, victims from 136 countries were detected in 118 countries (Sun-Suon 2015). In 2009, 59 percent of the victims were women (UNODC 2012), while 27 percent were children during the period 2007-2010 (IOM 2008). Looking at global scale of this phenomenon, Albania is not an exception.

Currently, this intolerable and unacceptable phenomenon represents one of the most profitable activities favoured not only by geographic position of Albania but also by seriously weak law enforcement (Meçe 2016). Despite efforts made by the Albanian government to address it over years, minimum standards are not met to eliminate human trafficking. Country is ranked in Tier 2 being both a country of origin and a country of destination (United States Department of State 2015).

Human trafficking is analysed from various perspectives which have suggested different ways to tackle it. Barner, Okech and Camp (2014) discussed it within the framework of socio-economic inequality underlining that human trafficking is one of the most serious effects of inequality derived from unequal power relations globally created. They call for adoption of strategies that reduce social and economic inequality to combat human trafficking (Barner, Okech \& Camp 2014). Zimmerman, Hossain and Watts (2011) analysed human trafficking as a life threatening health issue embedded in various forms of abuse and exploitation. They call for application of multi-sectoral strategies, including health sector, to protect and recover human victims. Shelley (2010) viewed human trafficking as an international crime caused by fastly grown world conditions for demand and supply during globalization. Relying on coercion, brutality and corruption, strategies to combat it require multilateral efforts including a large coordinated international advocacy movement, state border control 
and international security (Shelley 2010). Another framework views human trafficking as a migration issue where there is interplay of ever-tighter migration controls with the presence of criminals who like to take advantage on the paradox of migration controls (Friesendorf 2009).

Human trafficking is based on a wide range of assumptions. Some assume that human trafficking is focused on sexual exploitation only because it generates the highest profit (Belser 2005). Therefore, trafficking for labour exploitation has been rarely tackled. In fact, it has been mainly viewed as an issue which can be regulated by labour code rather than a problem which can be present as both, sexual exploitation and labour exploitation. Inadequate legislation has been unable to address this issue (Bosco, di Cortemiglia and Serojitdinov 2009). Another assumption shows that small number of traffickers prosecuted means that this phenomenon is not so widespread. This does not mean that the scale of this phenomenon is low but there are a range of difficulties encountered to identify victims of trafficking and collect exact data (Bosco, di Cortemiglia \& Serojitdinov 2009).

This paper applies human rights-based approach to discuss the dynamics of human trafficking in Albania and analyse the effectiveness of the counter-trafficking response of the Albanian government with a special emphasis on prevention, protection and prosecution. A rights-based approach to human trafficking aims at analysing the ways how violation of human rights arises throughout the trafficking cycle and how the State fulfils its obligations under international human rights law. It intends to promote human rights perspective in all anti-trafficking measures taken and ensure that protection of human rights is at the core of all interventions and policies (UNHROHC 2014).

Various articles and papers have been written about this phenomenon in Albania and its consequences on its society as a whole, but few of them have analysed it from a rights-based approach (Campbell 2013; CRCA 2012; ECPAT 2012; Friman \& Reich 2007; Muço 2013). From this standpoint, this paper will be an added contribution to the ongoing efforts made to 
comprehensively analyse this phenomenon and recommend suitable strategies to combat it accordingly.

\section{Methods and paper organization}

This paper addresses two main research questions: 1) What are the dynamics of human trafficking in Albania? and 2) How effective is counter-trafficking response of the Albanian government with a special emphasis on prevention, protection and prosecution? To answer to these questions, this paper is based on secondary data and literature review. Secondary data are used to describe the context, scale, nature and dynamics of human trafficking in Albania. Some comparisons are also made with some neighbouring countries to get a broader overview of this phenomenon. Literature review is based on reviewing of several country strategic documents, reports, legal framework and policy papers to assess the effectiveness of countertrafficking response especially on prevention, protection and prosecution.

This paper is composed of five parts. Following the first part which includes introduction and methods, the second part provides a general overview of the context of human trafficking in Albania including its definition, nature, type, scale and dynamics. A framework of the rightsbased approach to human trafficking has been described in the third part, while effectiveness of the counter-trafficking response has been critically analysed in the fourth part. Finally, some conclusions are drawn in the fifth part.

\section{Overview of the context of human trafficking in Albania}

Article 110/a of the Penal Code of the Republic of Albania defines human trafficking as 'recruitment, transportation, harbouring, or receipt of persons through threat or use of force or other forms of compulsion, abduction, deception, abuse of office, or taking advantage from the social, physical or psychological state, or the giving or receipt of payment or other benefits to 
obtain the consent of a person who controls another person, for the purpose of exploitation of others for prostitution, or other forms of sexual exploitation, work or compelled services, slavery or other forms similar to slavery, making use of or transplanting organs, as well as other forms of exploitation be punished with imprisonment from five to fifteen years and with a fine from two million to five million Albanian Lek. Organization, management and financing of the trafficking of persons sentenced to imprisonment from seven to fifteen years and with a fine from four million to six million Albanian Lek.' (Official Gazette 2004).

Human trafficking did not exist in Albania until 1990 because extreme country's isolation during the period of long-standing authoritarian regime strictly prohibited international involvement (IPEC 2004). Transition period during the years of economic transformation to capitalist system made Albania a place of insecurity. Unfamiliar with the rules of market economy and democracy (Campbell 2013), Albanians faced a range of challenges never experienced before, including extreme unemployment, massive immigration and emigration (IPEC 2004). Initially, massive illegal migration of Albanians to Western European countries since 1991 was not controlled due to lack of police manpower, expertise and funds (UNDP 2000). This simplified the work of formal and informal networks that became active in the process of human trafficking displacing marginalized people, increasing their incentives for migration and engaging them in organized criminal networks (Friman and Reich 2007).

The covert nature of the phenomenon of human trafficking has led to contesting of its conceptualization and extent in Albania due to lack of adequate and reliable data (ECPAT 2012; Friman and Reich 2007). However, various sources provide alarming data about the scale of human trafficking in Albania. An estimated number of 4,000 children have been trafficked to neighbouring countries mainly in Greece and Italy for begging, labour, sexual exploitation and slavery during the period 1992-2002 (IPEC 2004). The majority of these minors came from rural areas (about 48 percent) and 
52 percent of them had seven years of schooling or less than that (Marion 2012).

Even though prostitution is a relatively new phenomenon for Albanian society, the country is one of the main suppliers of prostitutes to various Western European countries (UNDP 2000). 5,000 Albanian women and girls worked as prostitutes in Greece (UNDP 2000); about 8,000 worked as prostitutes in Italy in 1998 while nowadays this number has spiked to 20,000 (Smith 2014). During the period 2012-2013, the total number of victims of human trafficking from Albania to the United Kingdom increased from 107 (in 2012) to 192 (in 2013) while 167 of them or 87 percent were involved in sexual exploitation (NCA 2014).

Main push factors contributing to human trafficking in Albania are diverse including poverty, unemployment, dysfunctional families, domestic violence, gender inequality and low level of education of parents (IPEC 2004; UNDP 2000). Among pull factors it is worthy to mention lack of law enforcement, lack of perspective within the country and hope for a better life abroad (IPEC 2004; UNDP 2000). Recruitment of women is fraudulently done by criminal groups who make them offers for employment abroad mainly in dancing, singing, waitressing and bartending (United States Department of State 2014). But, parental complacency in trafficking of girls and minors has also been recorded (Smith 2014).

Albanian women, girls and children are not only subject to international trafficking, but also to internal trafficking. Internal human trafficking has been reportedly increased in Albania particularly in relation with rural-urban migration and seasonal migration to touristic places (Council of Europe 2011). Albanian law does not have a standard definition on internal trafficking which is usually viewed as being synonymous with prostitution. Lack of this definition makes women engaged in sex work within the country to be considered as engaged in crime against 'morality and dignity', while attribution of victimhood to women trafficked abroad for sexual exploitation is lacking agency (Campbell 2013). Trafficking for sexual exploitation occurs internally and many girls and women are trafficked in 
main cities of the country where they are sexually exploited in prostitution. In 2009, half of the internally trafficked Albanian victims were women and girls involved in forced prostitution in hotels and private residences in Tirana, Durres and Vlora (ECPAT 2012).

But Albanian government has been very slow to recognize and acknowledge the phenomenon of human trafficking in general (Friman and Reich 2007). Therefore, almost 25 years after the change of its political system, it is a source and destination country for human trafficking mainly in Italy, Greece, Kosovo, Belgium, United Kingdom and Switzerland (United States Department of State 2014) including forced child begging (European Commission 2013). Domestic human trafficking is in rise and reports show that children have been involved not only in forced begging but also in prostitution (IPEC 2004; ECPAT 2012; CRCA 2012). Mostly members of vulnerable Roma community are exposed to it.

During the period 2001-2014, Albania's Tier ranking has moved between Tier 2 Watch List to Tier 2 (does not fully comply with minimum standards of Trafficking Victims Protection Act) (United States Department of State 2014). Figure 1 shows the trend of Albania's Tier ranking over years.

Figure 1: Albania tier ranking, 2001-2014

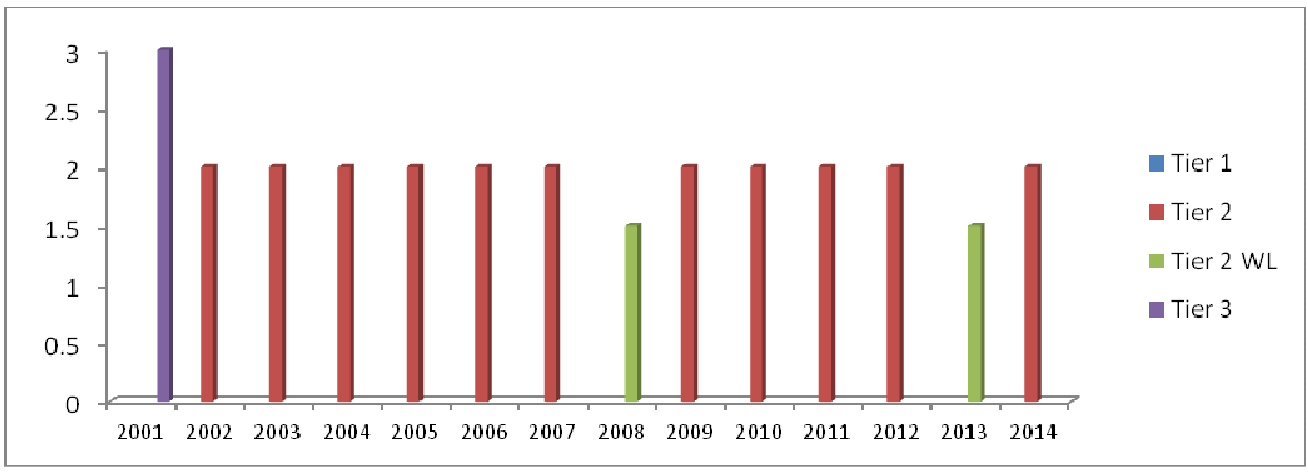

Source: United States Department of State Reports 2001 - 2014.

It is argued that the situation of human trafficking is complicated by 
the link between corruption in law enforcement and application of corrupt practices which in turn lead to the failure of the effective implementation of anti-trafficking response (Cho, Dreher and Neumayer 2014; van Dijk and Klerx-van Mierlo 2013). Bales (2005) considers corruption as a driving factor of human being trafficking. According to OSCE, corrupted public officials are unwilling to act against this phenomenon (Mann and Dolea 2006). Bad governance in source countries followed by weak governmental efforts to protect innocent people from exploitation and violation of their human rights has expanded their victimization (Cho, Dreher and Neumayer 2014) keeping this phenomenon going (Tremblay 2010). This creates distrust in the state institutions and increases reluctance of the citizens to report trafficking cases to respective authorities (Arsovska and Janssens 2009). Thus, overlooking this correlation, victims of human trafficking can be subject to double and triple victimization. On the other hand, corruption of public officials might impact them directly and indirectly. Even insufficient understanding of the phenomenon of human trafficking or the use of the public office for private gains facilitates the functioning of this phenomenon (Holmes 2009).

But Albania is one of the former socialist countries of the Western Balkan region which has a non-consolidated democratic system. Disappointment with democracy has been increased questioning democratic transition of the country (The Economist Intelligence Unit 2016). Even though the definition of the term democracy is contested, at a minimum, its fundamental features imply respect for basic human rights and equality before the law. But lack of many necessary conditions for de facto democracy has been followed by very low levels of public confidence on institutions (The Economist Intelligence Unit 2016).

Furthermore, the context of human trafficking in Albania should not be seen in isolation from the regional context of Western Balkan, as a whole (Meçe 2016). Various reports indicate multiple dynamics played within and between individual Western Balkan countries of this region (Friman and Reich 2007) characterized by widespread corruption, fragile democracy and 
organized crime networks. Measures used to rank corruption, democracy and human trafficking show some fluctuating results at regional level. The Corruption Perceptions Index produced by Transparency International is a composite index aiming at measuring the perceived extent of corrupt practices in countries based on different sources (Transparency International 2015). In 2015, the Corruption Perception Index for Albania scored 36 ranking it $88^{\text {th }}$ among 168 countries (Transparency International 2015).

Table 1: Corruption Perception Index, Democracy Index and Tier ranking of Western Balkan countries, 2015

\begin{tabular}{|c|c|c|c|c|c|c|}
\hline \multirow[t]{2}{*}{ Countries } & \multicolumn{3}{|c|}{$\begin{array}{c}\text { Democracy Index } \\
\text { (calculated for } 174 \text { countries) }\end{array}$} & \multicolumn{2}{|c|}{$\begin{array}{l}\text { Corruption Perceived Index } \\
\text { (calculated for } 168 \text { countries) }\end{array}$} & \multirow[t]{2}{*}{$\begin{array}{c}\text { Tier } \\
\text { ranking }\end{array}$} \\
\hline & $\begin{array}{l}\text { score }(0 \\
\text { to } 10)\end{array}$ & $\begin{array}{c}\text { type of } \\
\text { democracy }\end{array}$ & rank & $\begin{array}{c}\text { score } \\
(0=\text { highly } \\
\text { corrupted; } \\
100 \text { = very clean })\end{array}$ & rank & \\
\hline Albania & 5.91 & $\begin{array}{l}\text { hybrid } \\
\text { regime }\end{array}$ & 81 & 36 & 88 & 2 \\
\hline $\begin{array}{l}\text { Bosnia \& } \\
\text { Herzegovina }\end{array}$ & 4.83 & $\begin{array}{l}\text { hybrid } \\
\text { regime }\end{array}$ & 104 & 38 & 76 & 2 \\
\hline Kosovo & $\mathrm{n} / \mathrm{a}$ & & & 33 & 103 & 2 \\
\hline Macedonia & 6.02 & $\begin{array}{c}\text { flawed } \\
\text { democracy }\end{array}$ & 78 & 42 & 66 & 1 \\
\hline Montenegro & 6.01 & $\begin{array}{c}\text { flawed } \\
\text { democracy }\end{array}$ & 79 & 44 & 61 & 2 \\
\hline Serbia & 6.71 & $\begin{array}{c}\text { flawed } \\
\text { democracy }\end{array}$ & 58 & 40 & 71 & 2 \\
\hline
\end{tabular}

Source: The Economist Intelligence Unit 2016; Transparency International 2015; United States Department of State Report 2015.

Moreover, Democracy Index based on 60 indicators grouped in five categories respectively, pluralism, civil liberties, the functioning of government, political participation and political culture provides information about the type of regime of each country. Four types of regimes are categorized respectively, full democracy, flawed democracy, hybrid regime and authoritarian regime (The Economist Intelligence Unit 2016). In 2015, Democracy Index for Albania scored 5.91 ranking it 81 st among 174 
countries and indicated a hybrid regime. This type of regime means that there are serious weaknesses in functioning of the government in the country where corruption tends to be widespread and the rule of law is weak (The Economist Intelligence Unit 2016). Table 1 shows that Corruption Perceptions Index, Democracy Index and human trafficking (Tier ranking based on how governments comply with the minimum standards of Trafficking Victims Protection Act) have unsatisfied performance creating not a good image for the region, in general, and for Albania, in particular. From a policy perspective this would call for a better prioritization and integration of anti-trafficking interventions in practice.

\section{Conceptual framework of rights-based approach to human trafficking}

Human trafficking deprives human rights of women, children and men (Sun-Suon 2015). They are treated as commodities and brutally used, reused, purchased and sold several times (Aston and Paranjape 2013). Its consequences are devastating for its victims (Shelley 2010). Violation of human rights of trafficked persons is incompatible with international human rights law. Article 1 and Article 2 of the Universal Declaration of Human Rights state that rights are universal and applied to every one without discrimination on the basis of race, colour, sex, language, religion and other distinctions. Article 8 of the International Covenant on Civil and Political Rights prohibits forced or compulsory labour, slavery and servitude (UN 1966).

Moreover, human trafficking is also a worst form of gender-based violence against women and girls (OHCHR et al. 2011). Article 6 of the Convention on the Elimination of all forms of Discrimination against Women (CEDAW) prohibits all forms of trafficking of women and their exploitation for prostitution (UN 1979). Article 35 of the UN Convention on the Rights of the Child prohibits trafficking of children for any purpose or in any form (UN 1989). Article 3 of the ILO Convention No. 182 on the Worst Forms of Child Labor prohibits child's slavery and all similar practices 
related to slavery including child trafficking, forced or compulsory labour and child prostitution (ILO 1999). Therefore, a human rights-based approach to human trafficking is needed to ensure effective protection of human rights of victims (Dottridge 2006).

A human rights-based approach to trafficking is a conceptual framework based on international human rights standards aiming at promoting and protecting human rights. This methodology serves as a guideline to monitor and evaluate counter-trafficking responses from a rights-based approach (OHCHR et al. 2011). It is guided by the principles of universality of all rights, non-discrimination, equality (Dottridge 2006; UNHROHC 2014), participation and accountability with special emphasis on gender implications and child victims implications (OHCHR et al. 2011). Putting human rights of trafficked persons at the centre of all efforts made to combat human trafficking, it analyses both the ways how violation of human rights arises throughout the trafficking cycle and the obligations of the state to fulfil international human rights law (UNHROHC 2014).

Trafficked persons should be seen as rights holders rather than as mere instruments to investigation and prosecution (OHCHR et al. 2011). Their trafficking cannot be simply reduced to a mere problem related to migration, a public order concern or an organized crime attempt. It means that all those involved in anti-trafficking efforts should integrate human rights in both, problem analyses and response design (UN 2010). Therefore, a human rights-based approach to trafficking guarantees that countertrafficking responses do not negatively impact their human rights and do not discriminate against women and other vulnerable groups (OHCHR et al. 2011). This is also demanded in the Article 2 of the Protocol to Prevent, Suppress and Punish Trafficking in Persons, especially Women and Children, Supplementing the United Nations Convention against Transnational Crime (referred as Trafficking Protocol). It clearly states that this protocol intends a) to prevent and combat trafficking of persons particularly women and children; b) to protect and assist victims of trafficking fully respecting their human rights (UN 2000). 
On the other hand, a human rights-based approach to trafficking seeks to empower individuals and strengthen their participation and ability to govern their lives (OHCHR et al. 2011). It also works to raise the capacities of duty bearers to fulfil their legal obligations (UNHROHC 2014). Countertrafficking response focuses on prevention of human trafficking, protection of victims and prosecution of traffickers (IOM 2008).

Prevention seeks to undertake positive measures to stop future occurring of human trafficking. It focuses on the main causes of trafficking which increase the vulnerability of victims, create demand for services provided by trafficked people and create or sustain environment within which traffickers easily operate (UNHROHC 2014). Protection of trafficked victims intends to keep them safe taking into consideration their basic needs and enjoyment of human rights. Prosecution is an important element for the government to eradicate human trafficking focusing on implementation of specific anti-trafficking laws and capacity (Sun-Suon 2015).

\section{Effectiveness of counter-trafficking response in Albania}

In this paper, effectiveness of counter-trafficking response refers to three components: a) the effectiveness of prevention of trafficking; b) the effectiveness of the protection of victims of trafficking; $c$ ) the effectiveness of prosecution of traffickers.

The primary source of obligation of the State to combat human trafficking derives from treaties which legally bind it to international human rights law (UNHR 2014). Article 9 of the Trafficking Protocol demands State Parties to adopt measures that discourage the demand that fosters exploitation of people, in general, and of women and children, in particular, leading to their trafficking. Albania has a broad-based legislation to combat human trafficking which evolved after the year 2000. It has ratified all major United Nations Conventions and has gradually adopted its domestic legislation to bring it in line with international human rights law and its 
standards. Various national strategies and national action plans have been updated to combat human trafficking.

Provisions of the Albanian Criminal Code have also been amended. So, organization, management and financing of the trafficking of human beings is sentenced 7-15 years imprisonment plus a fine of 4-6 million Albanian Lek. If the act is conducted in collaboration with others, or repeatedly, or accompanied by mistreatment where the victim has been forced to conduct various actions because of the use of physical or psychological force which has caused serious harm of victim's health, then the sentence should be less than 15 years imprisonment plus a fine of 6-8 million Albanian Lek. If the act has caused the death of trafficked person then the sentence should be not less than 20 years imprisonment or life imprisonment plus a fine of 7-10 million Albanian Lek. However, several challenges which hinder effective response to this severe social dangerous phenomenon respectively, in prevention, protection and prosecution.

\section{Prevention}

Articles 5 and 6 of the Council of Europe Convention on Action against Trafficking in Human Beings (2005) oblige State Parties to take a range of measures to establish or strengthen national coordination among responsible duty bearers to combat human trafficking; to establish or strengthen effective policies and programs to prevent human trafficking including awareness raising of vulnerable groups to trafficking; to promote a human rights-based approach using gender mainstreaming and a child-sensitive approach; to take specific measures to reduce children's vulnerability; to take measures to discourage demand by addressing causes of human trafficking and gender-based discrimination.

But, the current situation in Albania shows that:

a) There is a lack of the legal definition of internal trafficking making it unaddressed. Current legal framework of Albania includes measures that chiefly target transnational trafficking, but it does not handle with domestic trafficking (ECPAT 2012). The existing definition of human trafficking 
adopted by Albania does not require the crossing of an international border and does not always require movement. It also covers internal and crossborder trafficking and extends to the maintenance of the person in an exploitative situation (UNHR 2014).

b) Insufficient awareness raising campaigns have been organized to prevent human trafficking. Multi-actors cooperation has not been consistently strengthened to ensure smooth implementation of policies and encourage execution of joint actions by application of good human rightsbased operational platforms at local and national levels. For instance, regional anti-trafficking groups have not been regularly functioned because of lack of assistance and leadership (ECPAT 2012).

c) Albania is a source country for child trafficking, forced child labour and the worst forms of child labour as per definition provided in ILO Convention No. 182 (European Commission 2015). No national plan is in place to prevent child prostitution (CRCA 2012).

d) Vulnerabilities that make particular social groups subject to human trafficking have not been addressed. Gendered impact of human trafficking has not been well understood to avoid discriminatory practices and disrespectful actions. So, gender-based violence remains problematic because of the poor functioning of the established mechanisms. On-line reporting of cases is operational in 29 out of 61 municipalities increasing the total number of unreported cases (European Commission 2015). Women's labour and social rights are violated. The women to men wage gap increased from 19.51 percent in 2009 to 28 percent in 2012 (INSTAT 2013). Labour force participation rate is 56.6 percent for women versus 74.3 percent for men increasing poverty among women (INSTAT 2013).

e) High percentage of Roma women and children involved in internal trafficking shows that the Albanian Government has not systematically prioritized the improvement of the living conditions of this marginalized community. Even though it has been committed to implement Roma Inclusion Decade (2005-2015) and adopted National Action Plan (2010-2015) (Official Gazette 2010), it has been unable to successfully achieve its 
objectives towards social inclusion and socio-economic empowerment of this community (Decade of Roma Inclusion Secretariat Foundation 2013).

f) Mapping of those exposed at risk of trafficking has not been properly done. Multiple sources of information have not been sufficiently utilized to provide a comprehensive analysis of the existing policies and strategies in order to identify existing gaps and close them accordingly.

\section{Protection}

Articles $10-16$ of the Council of Europe Convention on Action against Trafficking in Human Beings (2005) oblige State Parties to take a range of measures to protect victims of human trafficking including their identification, protection of their private life, assistance, recovery period, residence permit, compensation and legal redress as well as repatriation and return.

But, the current situation in Albania shows that:

a) The Albanian government has not effectively applied a victimcentred and human rights-based approach to ensure full respect of the rights of the victims of trafficking. Even though information about victims' sociocultural background and factors that forced them be abused by the traffickers are very important to make an adequate assessment of their protection needs, high turnover rate among police officers has negatively impacted proactive investigation (ECPAT 2012; United States Department of State 2015).

b) It has failed to protect children from sexual exploitation and prostitution (CRCA 2012). New criminal provisions of the Albanian Criminal Code did not achieve expected outcomes because the justice system failed to punish those who sexually exploited children. The Memorandum of Understanding between the Ministry of Interior and the Ministry of Tourism, Culture, Youth and Sport, and OSCE in Albania in 2007 to protect children from sexual exploitation in tourism did not record any result. None of them reported about the total number of children protected from that memorandum (CRCA 2012). 
c) Direct financial assistance is provided to the victims of trafficking for their reintegration in the society, but they are reluctant to participate in legal proceedings because of fear from their traffickers. Even though the Albanian government appointed one victim-witness coordinator and two specialized prosecutors on human trafficking issues, it failed to protect them and forced them to rely on NGO support (ECPAT 2012).

d) Lack of coordination with NGOs has led to task overlapping, role duplicating or under covering of victims of trafficking. Total number of victims identified in 2013 increased, but state-run shelters had inadequate capacities to offer psychological, medical and reintegration services, and were in poor conditions. NGO-run shelters have been underfunded by the Government because it did not disburse its fund from the Special Fund for Crime Prevention (United States Department of State 2015).

e) Albanian government amended in 2014 the law to provide free health care for about 200 victims yearly, but none of them benefited due to the lack of guidelines from the government (United States Department of State 2015).

f) Albanian government is implementing a program which aims at providing incentives to some companies to hire former victims of trafficking, but it does not properly work. It was reported that some companies forced them to work without proper compensation (United States Department of State 2015).

g) Police officers, health care practitioners and other duty bearers have been trained on victim identification, but prosecutors outside Tirana lack capacity on working with victim witnesses (United States Department of State 2015). Regional discrepancies in implementation of capacity building activities negatively impact the quality of their work leading to undesired results.

\section{Prosecution}

Laws are not fully implemented in Albania leading to weak promotion and internalization of democratic values. Lack of systematic analysis of 
shortcomings on trafficking-related provisions of the Criminal Code has hindered clarification of trafficking offences for the purpose of sexual exploitation versus exploitation of prostitution with aggravating circumstances (Council of Europe 2011). Even though victim identification has been increased, prosecution of traffickers has been very slow and in low numbers. Data from Table 2 shows that many of them have been in free condition during the period 2005-2012.

Table 2: Statistics on human trafficking in Albania, 2005-2012

\begin{tabular}{|l|c|c|c|c|c|c|c|c|}
\hline Offence act & $\mathbf{2 0 0 5}$ & $\mathbf{2 0 0 6}$ & $\mathbf{2 0 0 7}$ & $\mathbf{2 0 0 8}$ & $\mathbf{2 0 0 9}$ & $\mathbf{2 0 1 0}$ & $\mathbf{2 0 1 1}$ & $\mathbf{2 0 1 2}$ \\
\hline $\begin{array}{l}\text { Authors } \\
\text { (Total) }\end{array}$ & 23 & 33 & 23 & 26 & 17 & 51 & 34 & 26 \\
\hline Arrested & 7 & 15 & 7 & 4 & 1 & 8 & 10 & 5 \\
\hline Stopped & 2 & 0 & 2 & 14 & 12 & 3 & 3 & 1 \\
\hline Free condition & 12 & 8 & 12 & 5 & 1 & 37 & 18 & 18 \\
\hline Wanted & 2 & 10 & 2 & 3 & 3 & 3 & 3 & 2 \\
\hline
\end{tabular}

Source: Muço (2013)

Lack of proactive operations to tackle criminal networks of human trafficking has been combined with corruptive practices that have undermined efficient investigation and prosecution. Official complicity in human trafficking including some members of the Albanian Parliament remains a big concern (United States Department of State 2015). High turnover rate among police officers has prohibited prosecution of traffickers (United States Department of State 2015). But, prosecution of traffickers in Albania is also hindered by the existence of the provision for double criminality. Article 6 of the Albanian Criminal Code is applied to Albanians who commit crime within the Albanian territory. Albanians who commit crimes abroad can be punished when alleged crime is jurisdictionary recognized by both states (ECPAT 2012). 


\section{Conclusions}

As the nature of human trafficking is becoming internationalized, countertrafficking response is becoming complex (Sun-Suon 2015). This paper indicated that counter-trafficking response in Albania has been ineffective despite various efforts made by the Albanian government to tackle it. Rights-based approach to address human trafficking has been weak marking a range of structural, legal, financial, cultural and operational shortcomings caused by various factors.

Country's legal framework does not have a clear definition of human trafficking disregarding internal trafficking and mainly focusing on sexual exploitation. This narrow definition leads to few investigations and draws an incomprehensive and incomplete picture about the scale of other forms of human trafficking. Inadequate protection of victims makes them more vulnerable and unable to testify. Existence of interdependent self-culture which is influenced by others creates complex situations that expose victims of human trafficking to prejudice and stigma. Usually referred as prostitutes, their image is destroyed. Their stigmatization and the culture of shame increase their reluctance to report the traffickers leading to underreporting of criminal cases. On the other hand, the main causes of their vulnerabilities are not fully addressed. Especially women and girls with low socioeconomic background and from minority groups such as Roma population remain exposed to it. Measures taken to alleviate lack of equal opportunities, minimize gender gap in employment and decrease poverty level did not provide successful outcomes. Finally, more sustainable actions should be taken to protect and respect victims of trafficking including criminalization of the phenomenon itself.

\section{References}

Arsovska, Jana and Stef Janssens. 2009. 'Human trafficking \& policing: good \& bad practices.' In Strategies against human trafficking: The role of the 
security sector, edited by Cornelius Friesendorf, 169-213. Vienna: National Defence Academy and Austrian Ministry of Defence and Sports.

Aston, Joshua N. and Vinay N Paranjape. 2013. 'Victims of human trafficking: A human rights perspective.' Social Science Research Network [online]. Available at: papers.ssrn.com/sol3/papers.cfm? abstract_id=2237914 [accessed 5 December 2015].

Bales, Kevin. 2005. Understanding Global Slavery: A Reader. Berkeley and Los Angeles: University of California.

Barner, John. R., David Okech, and Megan A. Camp. 2014. 'Socio-economic inequality, human trafficking, and the global slave trade.' Societies 4(2): 148-160.

Belser, Patrick. 2005. Forced Labour and Human Trafficking: Estimating the Profits. International Labor Migration [online]. Available at: http://www.ilo.org/wcmsp5/groups/public/-ed_norm/declaration/documents/publication/wcms_081971.pdf [accessed 30 June 2010].

Bosco, Francesca, Vittoria. L. di Cortemiglia, and Anvar Serojitdinov. 2009. 'Human trafficking patterns.' In Strategies against human trafficking: The role of the security sector, edited by Cornelius Friesendorf, 35-83. Vienna: National Defence Academy and Austrian Ministry of Defence and Sports.

Campbell, P. James. 2013. 'Shaping the victim: borders, security, and human trafficking in Albania.' Anti-trafficking Review 2: 81-96. Available www.antitraffickingreview.org [accessed 29 November 2015].

Cho, Seo-Young, Axel Dreher, and Eric Neumayer. 2014. 'Determinants of anti-trafficking policies: Evidence from a new index.' The Scandinavian Journal of Economics 116(2): 429-454.

Council of Europe. 2005. Council of Europe Convention on Action against Trafficking in Human Beings. [online]. Available at https://www.gov.uk/government/uploads/system/uploads/attac hment_data/file/236093/8414.pdf [accessed 30 November 2015].

Council of Europe. 2011. GRETA, Group of Experts on Action against Trafficking in Human Beings. Report concerning the implementation of the Council of Europe Convention against Trafficking in Human Beings by Albania, 2 December 2011. [online]. Available at http://www.coe.int/ t/dghl/monitoring/trafficking/Docs/reports/GRETA_2011_22_FG R_ALB_en.pdf [accessed 28 November 2015].

CRCA. 2012. Albania. Alternative report to the Optional Protocol of the Convention on the Rights of the Child on the sale of children, child 
prostitution and child pornography. Tirana, Albania.

Decade of Roma Inclusion Secretariat Foundation. 2013. Civil Society Monitoring Report on the Implementation of the National Roma Integration strategy and Decade Action Plan 2012 in Albania. Available at www.romadecade.org [accessed 25 October 2015].

Dottridge, Mike. 2006. Action to prevent child trafficking in South Eastern Europe. UNICEF and Terre des hommes.

ECPAT. 2012. Global monitoring status of action against commercial sexual exploitation of children: Albania. $2^{\text {nd }}$ Edition. Thailand: ECPAT International.

European Commission. 2015. Albania 2015 Report. [online]. Available at ec.europa.eu [accessed 29 November 29, 2015].

Friesendorf, Cornelius. 2009. 'Introduction: The security sector and countertrafficking.' In Strategies against human trafficking: The role of the security sector, edited by Cornelius Friesendorf, 17-33. Vienna: National Defence Academy and Austrian Ministry of Defence and Sports.

Friman, Richard H. and Simon Reich. 2007. Human trafficking and the Balkans. Pittsburgh: University of Pittsburgh Press.

Holmes, Leslie. 2009. 'Human trafficking \& corruption: Triple victimization?' In Strategies against human trafficking: The role of the security sector, edited by Cornelius Friesendorf, 83-115. Vienna: National Defence Academy and Austrian Ministry of Defence and Sports.

ILO. 1999. Convention No. 182 on the Worst Forms of Child Labor. ILO. [online]. Available at http://www.ilo.org/wcmsp5/groups/public/--ed_norm/---declaration/documents/publication/wcms_decl_fs_46_ en.pdf [accessed 2 December 2015].

INSTAT. 2013. Women and men in Albania. Tirana.

IOM. 2008. Handbook on performance indicators for counter-trafficking projects. Washington, DC.

IPEC. 2004. Regional assessment of trafficking in children for labor and sexual exploitation in Albania. Tirana: ILO.

Mann, Lori and Igor Dolea. 2006. OSCE Trial Observation Manual for the Republic of Moldova. Chisinau: OSCE/ODIHR.

Meçe, Merita. H. 2016. 'Irregular migration flows and human trafficking in the Western Balkan countries: Challenges of the convergence of counter-trafficking response.' Journal of Liberty and International Affairs 1(Supp 1): 38-48.

Muço, Ervin. 2013. 'Trafficking in human beings: paradigms of a successful 
reintegration into society (Albanian case).' European Scientific Journal 9(4): 92-117.

NCA. 2014. National Crime Agency strategic assessment. The nature and scale of human trafficking in UK in 2013. UK.

Official Gazette. 2004. Law No. 9187 dated 12.02.2004 on Changes in the Penal Code. Official Gazette 13. 16 March 2004. [online]. Available at http:// www.qbz.gov.al/botime/fletore_zyrtare/2004/PDF-2004/ 13-2004.pdf [accessed 8 December 2015].

Official Gazette. 2010. Decision of Council of Ministers N. 1087 dated 28.10.2009 on Approval of National Action Plan of Roma Inclusion Decade 2010-2015. Official Gazette 68. Available at www.qbz.gov.al [accessed 8 December 2011].

OHCHR, UNHCR, UNICEF, UNODC, UN Women., and ILO. 2011. Prevent, combat, protect human trafficking. Joint UN Commentary on the EU Directive - A human rights-based approach.

Roth, Venla. 2012. Defining human trafficking and identifying its victims. Leiden: Martinus NIJHOFF Publishers.

Shelley, Louise. 2010. Human trafficking. A global perspective. Cambridge: Cambridge University Press.

Smith, Athena. 2014. 'Correlations of sex trafficking in three Balkan countries.' African Journal of Hospitality, Tourism and Leisure 3(1). [online]. Available at http://www.ajhtl.com/uploads/7/1/ 6/3/7163688/ article_3_vol_3._1_2014.pdf [accessed 8 December 2015].

Sun-Suon, Madevi. 2015. Human trafficking and the role of local governments. United Nations Institute for Training and Research \& CIFAL.

The Economist Intelligence Unit., 2016. Democracy Index 2015. Democracy in an age of anxiety. The Economist Intelligence Unit Limited. [online]. Available at www.eiu.com [accessed 24 July 2016].

Transparency International. 2011. Corruption and human trafficking. Working Paper 03/2011. Transparency International.

Transparency International. 2015. Corruption Perception Index 2015. [online]. Available at www.transparency.org [accessed 20 January 2016].

Tremblay, Maryse. 2010. Corruption and human trafficking: Unraveling the undistinguishable for a better fight. IACC Workshop Report, $14^{\text {th }}$ IACC (10-13 December 2010), Bangkok, Thailand.

UN. 1966. International Covenant on Civil and Political Rights. [online]. Available at http://www.ohchr.org/en/professionalinterest/ pages/ccpr.aspx [accessed 1 December 2015].

UN. 1979. Convention on the Elimination of all forms of Discrimination against 
Women. [online]. Available at http://www.ohchr.org/Documents/ ProfessionalInterest/cedaw.pdf [accessed 1 December 2015].

UN. 1989. Convention on the Rights of the Child. [online]. Available at http://www.ohchr.org/en/professionalinterest/pages/crc.aspx [accessed 1 December 2015].

UN. 2000. Protocol to Prevent, Suppress and Punish Trafficking in Persons, especially Women and Children, supplementing the United Nations Convention against Transnational Organized Crime. [online]. Available at http://www.osce.org/odihr/19223?download=true [accessed 2 December 2015].

UN. 2010. Recommended principles and guidelines on human rights and human trafficking. United Nations Human Rights Office of the High Commissioner for Human Rights. New York and Geneva. [online]. Available at http://www.ohchr.org/Documents/Publications/ Commentary_Human_Trafficking_en.pdf [accessed 30 November 2015].

UNDP. 2000. The Albanian Human Development Report 2000. Tirana, Albania.

UNFPA. 2007. Trafficking in human misery. UNFPA.

UNHROHC. 2014. Human rights and human trafficking. Factsheet N. 36. New York and Geneva: United Nations Human Rights Office of the High Commissioner.

United States Department of State. 2014. Trafficking in Persons Report 2014. [online]. Available at http://www.state.gov [accessed 25 November 2015].

United States Department of State. 2015. Trafficking in Persons Report 2015. [online]. Available at http://www.state.gov. [accessed 29 November 2015].

UNODC. 2012. Global report on trafficking in persons 2012. Vienna.

UNODC. 2014. Global report on trafficking in persons 2014. UN, New York.

USA Department of State. 2015. 2015 Trafficking in Persons Report. [online]. Available at www.state.gov [accessed 15 January 2016].

Van Dijk, Jan. and Fanny Klerx-van Mierlo. 2013. 'Revisiting the link between corruption prevalence and implementation failure in antitrafficking policies.' International Perspectives in Victimology 7(2): 1-8.

Zimmerman, Cathy, Mazeda Hossain, and Charlotte Watts. 2011. 'Human trafficking and health: A conceptual model to inform policy, intervention and research.' Social Science E Medicine 73(2): 327-335. 